\title{
Synthesis, Structural and Spectral Studies of Five- and Six-Coordinate Adducts of Organotin(IV) Halides Containing Dibenzylsulfoxide (dbso) as Ligand. The Crystal Structures of $f a c-\left[\mathrm{MeSnCl}_{3}(\mathrm{dbso})_{2}\right]$ and trans $-\left[\mathrm{Ph}_{2} \mathrm{SnCl}_{2}(\mathrm{dbso})_{2}\right]$
}

\author{
Gerimário F. de Sousa, ${ }^{*, a}$ José R. Sabino, ${ }^{b}$ Ivo Vencato, ${ }^{b}$ Carlos A. L. Filgueiras ${ }^{c}$ and José D. Ardisson ${ }^{d}$ \\ anstituto de Química, Universidade de Brasília, 70919-970 Brasília-DF, Brazil \\ ${ }^{b}$ Instituto de Física, Universidade Federal do Goiás, Campus Samambaia, 74001-970 Goiânia-GO, Brazil \\ 'Instituto de Química, Universidade Federal do Rio de Janeiro, 21495-970 Rio de Janeiro-RJ, Brazil \\ ${ }^{d}$ Laboratório de Física Aplicada, Centro de Desenvolvimento de Tecnologia Nuclear, \\ 30123-970 Belo Horizonte-MG, Brazil
}

\begin{abstract}
A reação do ligante ambidentado dibenzilsulfóxido (dbso) com $\mathrm{Me}_{2} \mathrm{SnCl}_{2}$ na proporção molar 1:1 leva à formação do produto pentacoordenado $\left[\mathrm{Me}_{2} \mathrm{SnCl}_{2}(\mathrm{dbso})\right]$, enquanto $\mathrm{Ph}_{2} \mathrm{SnCl}_{2}$ leva à formação do complexo hexacoordenado trans- $\left[\mathrm{Ph}_{2} \mathrm{SnCl}_{2}(\mathrm{dbso})_{2}\right]$, utilizando as mesmas condições de reação. Por outro lado, a reação com ${ }^{n} \mathrm{Bu}_{2} \mathrm{SnCl}_{2}$ forma o produto bimetálico $\left[\left\{{ }^{n} \mathrm{Bu}_{2} \mathrm{SnCl}_{2}(\mathrm{dbso})\right\}_{2}\right]$, o qual provavelmente possui núcleos de estanho(IV) octaédricos e cloretos em ponte. Os complexos $\left[\mathrm{MeSnCl}_{3}(\mathrm{dbso})_{2}\right]$ e $\left[\mathrm{Ph}_{3} \mathrm{SnCl}(\mathrm{dbso})\right]$ também foram preparados. Todos os produtos foram estudados por análise elementar e por espectroscopias no IV, RMN $\left({ }^{1} \mathrm{H},{ }^{13} \mathrm{C},{ }^{119} \mathrm{Sn}\right)$ e Mössbauer. As espécies hexacoordenadas fac- $\left[\mathrm{MeSnCl}_{3}(\mathrm{dbso})_{2}\right]$ e trans $-\left[\mathrm{Ph}_{2} \mathrm{SnCl}_{2}(\mathrm{dbso})_{2}\right]$ foram também estudadas por difratometria de raios $\mathrm{X}$; as determinações estruturais revelaram que estes compostos cristalizam-se nos sistemas cristalinos ortorrômbico, $P b c n$, e monoclínico, $P 2_{1} / c$, respectivamente. As moléculas possuem átomos de estanho(IV) numa geometria octaédrica distorcida, com os dois ligantes dbso em posições cis e trans, respectivamente.
\end{abstract}

The reaction of the ambidentate ligand dibenzylsulfoxide (dbso) with $\mathrm{Me}_{2} \mathrm{SnCl}_{2}$ in $1: 1$ molar ratio leads to the formation of the five-coordinate adduct $\left[\mathrm{Me}_{2} \mathrm{SnCl}_{2}(\mathrm{dbso})\right]$, whereas the same reaction conditions with $\mathrm{Ph}_{2} \mathrm{SnCl}_{2}$ provide the six-coordinate adduct trans- $\left[\mathrm{Ph}_{2} \mathrm{SnCl}_{2}(\mathrm{dbso})_{2}\right]$. On the other hand, the reaction with ${ }^{n} \mathrm{Bu}_{2} \mathrm{SnCl}_{2}$ forms the dimeric adduct $\left[\left\{{ }^{n} \mathrm{Bu}_{2} \mathrm{SnCl}_{2}(\mathrm{dbso})\right\}_{2}\right]$, which probably possesses octahedral tin(IV) nuclei and bridging chlorides. The adducts $\left[\mathrm{MeSnCl}_{3}(\mathrm{dbso})_{2}\right]$ and $\left[\mathrm{Ph}_{3} \mathrm{SnCl}(\mathrm{dbso})\right]$ were also prepared and included in the study. All complexes were studied by microanalysis and IR, NMR $\left({ }^{1} \mathrm{H},{ }^{13} \mathrm{C}\right.$ and $\left.{ }^{119} \mathrm{Sn}\right)$ and Mössbauer spectroscopies to investigate their structural properties. The six-coordinate species $f a c$ - $\left[\mathrm{MeSnCl}_{3}(\mathrm{dbso})_{2}\right]$ and trans-[ $\left.\mathrm{Ph}_{2} \mathrm{SnCl}_{2}(\mathrm{dbso})_{2}\right]$ were also studied by single crystal X-ray diffractometry. These compounds crystallize in the orthorhombic, $P b c n$, and monoclinic space group $P 2_{1} / c$, respectively, as discrete neutral molecules with the tin(IV) atom in a distorted octahedral geometry and the two dbso ligands in cis and trans positions, respectively.

Keywords: sulfoxide complexes, organotin(IV) complexes, crystal structure analyses

\section{Introduction}

Organotin(IV) compounds have demonstrated to exhibit wide biological activity. ${ }^{1,2}$ Insofar as many sulfoxides are also noteworthy for the same reasons, ${ }^{3}$ a combination of the two chemistries is an interesting line to pursue. Diorganotin(IV) dihalides, and more particularly $\mathrm{Me}_{2} \mathrm{SnCl}_{2}$,

*e-mail: gfreitas@unb.br form well-known 1:2 adducts with Lewis bases. ${ }^{4}$ However, both $\mathrm{Me}_{2} \mathrm{SnCl}_{2}$ and $\mathrm{Ph}_{2} \mathrm{SnCl}_{2}$ form 1:1 adducts ${ }^{5-7}$ with monodentate ligands, but reports on the isolation of both 1:1 and 1:2 adducts are scarce. ${ }^{8}$ The formation of $1: 1$ systems is curious and, surprisingly, neither the stoichiometry of the reactants nor the reaction conditions appear to exert much influence. ${ }^{4}$ The $1: 1$ adduct, $\left[\mathrm{Me}_{2} \mathrm{SnCl}_{2}(\mathrm{dbso})\right]$, whose $\mathrm{X}$-ray structure is already known, ${ }^{5}$ has been described as an authentic and unique five-coordinate trigonal bipyramidal 
compound without any intermolecular contact. The structure of dbso is shown below.

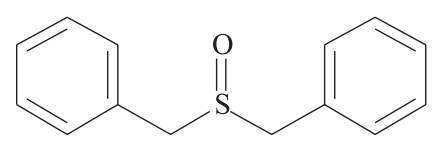

dbso

We report herein the preparation and spectroscopic investigation of five- and six-coordinate adducts involving $\mathrm{R}_{4-m} \mathrm{SnCl}_{m}\left(\mathrm{R}=\mathrm{Me},{ }^{n} \mathrm{Bu}, \mathrm{Ph}\right.$; and $\left.m=1,2,3\right)$ and dibenzylsulfoxide (dbso). The X-ray diffraction study of the adducts trans-dichloro-trans-bis(dibenzylsulfoxide)trans-diphenyltin(IV), trans- $\left[\mathrm{Ph}_{2} \mathrm{SnCl}_{2}(\mathrm{dbso})_{2}\right]$, and fac-trichloro-cis-bis(dibenzylsulfoxide)methyltin-(IV), $\mathrm{fac}-\left[\mathrm{MeSnCl}_{3}(\mathrm{dbso})_{2}\right]$, is also presented.

\section{Experimental}

\section{Material and procedures}

All starting compounds and reagents were of highest grade and were used without purification. IR spectra were recorded from $\mathrm{KBr}$ pellets on a Bomem MB100 FT-IR spectrometer in the $4000-400 \mathrm{~cm}^{-1}$ region. $\left({ }^{1} \mathrm{H},{ }^{13} \mathrm{C},{ }^{119} \mathrm{Sn}\right) \mathrm{NMR}$ spectra were run on a Varian Mercury Plus $300 \mathrm{MHz}$ spectrophotometer, using $\mathrm{CDCl}_{3}$ as solvent. Chemical shifts (ppm) are relative to TMS and $\mathrm{Me}_{4} \mathrm{Sn} .{ }^{119} \mathrm{Sn}$ Mössbauer spectra were collected at $77 \mathrm{~K}$ in the transmission geometry, on a conventional constant-acceleration spectrometer with a $\mathrm{CaSnO}_{3}$ source kept at room temperature. All isomer shift values reported in this work are given with respect to this source. All Mössbauer spectra were computerfitted assuming Lorentzian line shapes and the resulting isomer shifts and quadrupole splittings are accurate to $c a . \pm 0.05 \mathrm{~mm} \mathrm{~s}^{-1}$. The velocity calibration of the instrument was done at room temperature with ${ }^{57} \mathrm{Fe}$ enriched foil. The microanalyses were performed using a FISSONS CHNS, model EA 108 microanalizer.

Single-crystals of trans- $\left[\mathrm{Ph}_{2} \mathrm{SnCl}_{2}(\mathrm{dbso})_{2}\right]$ and $\mathrm{fac}$ $\left[\mathrm{MeSnCl}_{3}(\mathrm{dbso})_{2}\right]$, suitable for $\mathrm{X}$-ray studies, were obtained at room temperature as colourless solids by slow evaporation from EtOH/CHCl $3(3: 1, v / v)$ and $\mathrm{Me}_{2} \mathrm{CO}$ solutions, respectively. The data collection of trans$\left[\mathrm{Ph}_{2} \mathrm{SnCl}_{2}(\mathrm{dbso})_{2}\right]$ was performed using an Enraf-Nonius Kappa CCD diffractometer ${ }^{9}$ (Mo- $\mathrm{K}_{\alpha}$ radiation) with cold $\mathrm{N}_{2}$ gas cooling of the sample crystal. Diffraction data for $\mathrm{fac}_{-}\left[\mathrm{MeSnCl}_{3}(\mathrm{dbso})_{2}\right]$ were collected using an EnrafNonius CAD-4 diffractometer ${ }^{10}\left(\mathrm{Cu}-\mathrm{K}_{\alpha}\right.$ radiation $)$ at room temperature, and data reduction was performed using the XCAD-4 program. ${ }^{11}$

\section{Synthesis}

$\mathrm{Ph}_{3} \mathrm{SnCl}(0.5 \mathrm{~g}, 1.3 \mathrm{mmol})$ and dbso (0.3 g, $\left.1.3 \mathrm{mmol}\right)$ were dissolved in EtOH $(30 \mathrm{~mL})$. The solution was stirred at $70{ }^{\circ} \mathrm{C}$ for $2 \mathrm{~h}$. The hot colorless solution was then left to stand at room temperature to evaporate the solvent and colorless crystals of $\left[\mathrm{Ph}_{3} \mathrm{SnCl}(\mathrm{dbso})\right]$ were separated. All the other diorgorganotin(IV) adducts were obtained by slow evaporation of a $\mathrm{CHCl}_{3}$ solution containing the appropriate diorganotin(IV) dihalide and dbso in 1:1 molar ratio; the products were then recrystallized from a suitable solvent. Attempts to prepare $\left[\mathrm{Me}_{2} \mathrm{SnCl}_{2}(\mathrm{dbso})_{2}\right](1: 2)$ and $\left[\mathrm{Ph}_{2} \mathrm{SnCl}_{2}(\mathrm{dbso})\right](1: 1)$ were unsuccessful.

dbso: ${ }^{1} \mathrm{H}-\mathrm{NMR}\left(300 \mathrm{MHz}, \mathrm{CDCl}_{3}\right): \delta 7.43-7.26(\mathrm{~m}$, $10 \mathrm{H},-\mathrm{Ph}) ; 3.92$ (dd, $J 12$ and $\left.15 \mathrm{~Hz}, 4 \mathrm{H},-\mathrm{CH}_{2}-\mathrm{Ph}\right)$. ${ }^{13} \mathrm{C}-\mathrm{NMR}\left(300 \mathrm{MHz} \mathrm{CDCl}_{3}\right): \delta 57.1(\mathrm{C}-\mathrm{Ph}), 130.0(o-\mathrm{C})$, 128.8 (p-C), 128.8 (m-C), 128.2 ( $q-\mathrm{C})$.

[ $\mathbf{M e}_{2} \mathbf{S n C l}_{2}$ (dbso)]: ${ }^{1} \mathrm{H}$ NMR (300 $\mathrm{MHz} \mathrm{CDCl}_{3}$ ): $\delta$ 7.43-7.26 (m, 10H, -Ph); 3.97 (dd, J 13 and $14 \mathrm{~Hz}$, $\left.4 \mathrm{H},-\mathrm{CH}_{2}-\mathrm{Ph}\right) ; 1.06\left(\mathrm{~s}, 6 \mathrm{H}, \mathrm{Sn}-\mathrm{CH}_{3},{ }^{2} J\left({ }^{119} \mathrm{Sn}-{ }^{1} \mathrm{H}\right)=75.3\right.$ $\mathrm{Hz}) .{ }^{13} \mathrm{C}$ NMR $\left(300 \mathrm{MHz}, \mathrm{CDCl}_{3}\right): \delta 130.3$ (o-C), 129.0 (p-C), 128.8 (m-C), 128.7 (q-C); 55.8 (C-Ph), 9.9 (Sn-C, $\left.{ }^{1} J\left({ }^{119} \mathrm{Sn}-{ }^{13} \mathrm{C}\right)=568 \mathrm{~Hz}\right)$. Anal. calcd. for $\mathrm{C}_{16} \mathrm{H}_{20} \mathrm{Cl}_{2} \mathrm{OSSn}$ : C, 42.71; H, 4.48; S, 7.12\%. Found: C, 41.24; H, 4.64; S, 7.18\%. Yield $90 \%$; m.p. $117-118{ }^{\circ} \mathrm{C}$.

[Ph $\mathbf{P h}_{2} \mathbf{S n C l}_{2}$ (dbso) $)_{2}$ ]: ${ }^{1} \mathrm{H}$ NMR (300 $\left.\mathrm{MHz} \mathrm{CDCl}_{3}\right)$ : $\delta$ 7.76-7.23 (m, 30H, -Ph); 3.89 (dd, J 15 and $18 \mathrm{~Hz}$, $\left.4 \mathrm{H},-\mathrm{CH}_{2}-\mathrm{Ph}\right) .{ }^{13} \mathrm{C} \mathrm{NMR}\left(300 \mathrm{MHz}, \mathrm{CDCl}_{3}\right): \delta 130.3(o-$ C), 129.2 (p-C), 129.0 ( $m$-C), 128.6 ( $q$-C); 55.9 (C-Ph). Anal. calcd. for $\mathrm{C}_{40} \mathrm{H}_{38} \mathrm{Cl}_{2} \mathrm{O}_{2} \mathrm{~S}_{2} \mathrm{Sn}$ : C, 59.72; H, 4.76; S, 7.97\%. Found: C, 59.61; H, 4.81; S, 8.09\%. Yield 60\%; m.p. $127-128^{\circ} \mathrm{C}$.

[ ${ }^{n} \mathbf{B u}_{2} \mathbf{S n C l}_{2}$ (dbso)]: ${ }^{1} \mathrm{H}$ NMR (300 $\mathrm{MHz}, \mathrm{CDCl}_{3}$ ): $\delta 7.43-7.26(\mathrm{~m}, 10 \mathrm{H},-\mathrm{Ph}) ; 3.93(\mathrm{dd}, J 12$ and $15 \mathrm{~Hz}, 4 \mathrm{H}$, $\left.-\mathrm{CH}_{2}-\mathrm{Ph}\right) ; 1.77\left(\mathrm{~m}, 4 \mathrm{H},-\mathrm{CH}_{2}-\mathrm{Ph}\right) ; 1.77\left(\mathrm{~m}, 4 \mathrm{H},-\mathrm{CH}_{2}-\right.$ $\mathrm{Sn}) ; 1.39$ (m, 8H,); 0.94 (t, 6H, Sn-C-C-CH $).{ }^{13} \mathrm{C}$ NMR $\left(300 \mathrm{MHz}, \mathrm{CDCl}_{3}\right): \delta 130.2(o-\mathrm{C}), 129.1(p-\mathrm{C}), 129.0$ ( $m-\mathrm{C}), 128.7$ (q-C); 55.1 (C-Ph), Sn-C(28.9)-C(27.0)$\mathrm{C}(26.2)-\mathrm{C}(13.5)$. Anal. calcd. for $\mathrm{C}_{22} \mathrm{H}_{32} \mathrm{Cl}_{2} \mathrm{OSSn}$ : C, 49.47; H, 6.04; S, 6.00\%. Found: C, 48.21; H, 6.09; S, 6.21\%. Yield 80\%; m.p. $110-112{ }^{\circ} \mathrm{C}$.

$\left[\mathrm{MeSnCl}_{3}(\mathbf{d b s o})_{2}\right.$ ]: ${ }^{1} \mathrm{H}$ NMR (300 $\left.\mathrm{MHz}, \mathrm{CDCl}_{3}\right)$ : $\delta$ 7.40-7.25 (m, 10H, -Ph); 4.02 (s, 4H, - $\left.\mathrm{CH}_{2}-\mathrm{Ph}\right) ; 1.24$ $\left(\mathrm{s}, 3 \mathrm{H}, \mathrm{Sn}-\mathrm{CH}_{3},{ }^{2} \mathrm{~J}\left({ }^{119} \mathrm{Sn}-{ }^{1} \mathrm{H}\right)=123 \mathrm{~Hz}\right) \cdot{ }^{13} \mathrm{C}$ NMR $(300$ $\left.\mathrm{MHz}, \mathrm{CDCl}_{3}\right): \delta 130.6$ (o-C), 129.1 ( $p$-C), 129.0 ( $\left.m-\mathrm{C}\right)$, 128.0 (q-C). Anal. calcd. for $\mathrm{C}_{29} \mathrm{H}_{31} \mathrm{Cl}_{3} \mathrm{O}_{2} \mathrm{~S}_{2} \mathrm{Sn}: \mathrm{C}, 49.71 ; \mathrm{H}$, 4.46; S, 9.15\%. Found: C, 49.28; H, 4.72; S, 9.31\%. Yield $70 \%$; m.p. $147-149{ }^{\circ} \mathrm{C}$. 
[Ph ${ }_{3} \mathbf{S n C l}$ (dbso)]: ${ }^{1} \mathrm{H}$ NMR (300 MHz, $\left.\mathrm{CDCl}_{3}\right): \delta 7.80$ $-7.20(\mathrm{~m}, 25 \mathrm{H},-\mathrm{Ph}) ; 3.80\left(\mathrm{dd}, J 15\right.$ and $21 \mathrm{~Hz}, 4 \mathrm{H},-\mathrm{CH}_{2}-$ $\mathrm{Ph}) .{ }^{13} \mathrm{C}$ NMR $\left(300 \mathrm{MHz}, \mathrm{CDCl}_{3}\right): \delta 130.1(o-\mathrm{C}), 129.7$ ( $p$-C), 128.9 (m-C), 128.4 ( $q$-C); 56.6 (C-Ph). Anal. calcd. for $\mathrm{C}_{32} \mathrm{H}_{29} \mathrm{ClOSSn}$ : C, 62.42; H, 7.75; S, 5.21\%. Found: C, 61.04; H, 7.81; S, 5.19\%. Yield 50\%; m.p. 101-103 ${ }^{\circ} \mathrm{C}$.

\section{Crystal structure determination}

The initial structure solutions were obtained by the heavy-atom method using the SHELXS-97 program. ${ }^{12}$ The other non- $\mathrm{H}$ atoms positions were obtained by difference Fourier maps. Hydrogen atoms were placed in geometric positions with C-H distances in the range of 0.93-0.99 and refined with a riding model with their $\mathrm{U}_{\text {iso }}$ proportional to $\mathrm{U}_{\text {eq }}$ of their parent atoms. Non- $\mathrm{H}$ atoms were refined with anisotropic displacement parameters. For the adduct trans $-\left[\mathrm{Ph}_{2} \mathrm{SnCl}_{2}(\mathrm{dbso})_{2}\right]$, no correction for absorption was applied, and in $\mathrm{fac}$-[ $\left[\mathrm{MeSnCl}_{3}(\mathrm{dbso})_{2}\right]$ the rings were refined as idealized rigid groups with $\mathrm{C}-\mathrm{C}$ bond distances of $1.39 \AA$ A. All refinements were performed with full-matrix least-squares on $\mathrm{F}^{2}$, using the SHELXL-97 program. ${ }^{13}$ The data of $f a c-\left[\mathrm{MeSnCl}_{3}(\mathrm{dbso})_{2}\right]$ were corrected for absorption using the numerical method (Gaussian), with minimum and maximum transmission coefficients of 0.103 and 0.230 , respectively. The crystal data and details of data processing are given in Table 1.

\section{Results and discussion}

The structure of trans-[ $\left.\mathrm{Ph}_{2} \mathrm{SnCl}_{2}(\mathrm{dbso})_{2}\right]$

The molecular structure with the labelling scheme is shown in Figure 2 and the selected bond distances and angles are listed in Table 2. The arrangement about tin(IV) in trans- $\left[\mathrm{Ph}_{2} \mathrm{SnCl}_{2}(\mathrm{dbso})_{2}\right]$ is best described as a distorted octahedron geometry, in which the dbso molecules are well adapted for trans coordination. The coordination sphere is completed by two trans-phenyl and two trans-chloride groups and a slight distortion of the octahedron is observed. Thus, the angle $\mathrm{C} 31^{\mathrm{i}}-\mathrm{Sn} 1-\mathrm{C} 31$ is $177.3(3)^{\circ}$, and the other two trans bond angles $\mathrm{O} 1{ }^{\mathrm{i}}-\mathrm{Sn} 1-\mathrm{O} 1$ and $\mathrm{Cl} 1-\mathrm{Sn} 1-\mathrm{Cl} 2$ are $174.0(2)$ and $180^{\circ}$, respectively. The last angle indicates that the adduct possesses crystallographic two-fold axial symmetry with tin(IV) and both $\mathrm{Cl}$ atoms lying on the crystallographic two-fold axis. It is interesting to compare our results with literature data for the five-coordinate adduct $\left[\mathrm{Me}_{2} \mathrm{SnCl}_{2}(\mathrm{dbso})\right] .^{5}$ In trans-[ $\left.\mathrm{Ph}_{2} \mathrm{SnCl}_{2}(\mathrm{dbso})_{2}\right]$, the bond distance Sn1-O1 of 2.258(4) $\AA$ is significantly shorter than the equivalent bond distance value of 2.319(10) $\AA$ observed in $\left[\mathrm{Me}_{2} \mathrm{SnCl}_{2}(\mathrm{dbso})\right]$, indicating a stronger interaction in
$\mathrm{Ph}_{2} \mathrm{Sn}^{2+} / \mathrm{dbso}$ than in $\mathrm{Me}_{2} \mathrm{Sn}^{2+} / \mathrm{dbso}$. On the other hand, the Sn1-C31, 2.147(6); Sn1-Cl1, 2.578(2); and Sn1-Cl2, 2.509(2) $\AA$ bond lengths are considerably longer than the Sn1-C1, 2.128(15); Sn1-C2, 2.109(16); Sn1-Cl1, 2.392(6); and Sn1-Cl2, 2.464(6) A bond lengths found in $\left[\mathrm{Me}_{2} \mathrm{SnCl}_{2}(\mathrm{dbso})\right]$, as expected. The arrangement of the dbso ligands differs from that observed by Nardelli and collaborators ${ }^{14}$ in cis-dichloro-cis-bis(dimethylsulfoxide)trans-diphenyltin(IV), cis- $\left[\mathrm{Ph}_{2} \mathrm{SnCl}_{2}(\mathrm{dmso})_{2}\right]$, which has the chlorine atoms and the oxygen atoms cis, and the carbon atoms trans.

A sulfoxide coordinated to a metal via the oxygen atom can be represented formally by an $\mathrm{R}_{2} \mathrm{~S}^{\delta+}-\mathrm{O}^{\delta-}$ dipolar form, and coordination to an organotin(IV) species would be expected to lengthen the $\mathrm{S}-\mathrm{O}$ bond. This lengthening is observed in most organotin(IV)-sulfoxide complexes. ${ }^{5,15}$ This is corroborated by IR spectroscopy, which shows a lowering of $v(\mathrm{~S}-\mathrm{O})$ from 1033 to $969-988 \mathrm{~cm}^{-1}$ for all complexes under study here.

The structure of fac-[MeSnCl$\left({ }_{3}\left(\mathrm{dbso}_{2}\right]\right.$

The molecular structure with the labelling scheme is shown in Figure 1 and the selected bond distances and angles are listed in Table 2. The arrangement about tin(IV) in fac$\left[\mathrm{MeSnCl}_{3}(\mathrm{dbso})_{2}\right]$, located in a general position of the space group $P 2_{l} / c$, is a distorted octahedral geometry in which the three chlorides are arranged in a facial fashion and the dbso ligands are bonded by $\mathrm{O}$ atoms $c i s$ to one another. The trans position to the methyl group is occupied by a chlorine atom and not by the sulfoxide ligand, as observed in mer$\left[\mathrm{EtSnI}_{3}(\mathrm{dpso})_{2}\right]^{16}(\mathrm{dpso}=$ diphenylsulfoxide $)$. However, the adducts $m e r$-[ $\left.\mathrm{MeSnCl}_{3}(\mathrm{ImSOMe})\right], \mathrm{ImSOMe}=1$-methyl-2(methylsulfinylimidazole), and $m e r-\left[\mathrm{MeSnCl}_{3}\left(\mathrm{PySO}^{n} \mathrm{Pr}\right)\right]$, $\mathrm{PySO}^{n} \mathrm{Pr}=2$-( $n$-propylsulfinyl)pyridine, possess three chlorides arranged in a meridional position and the methyl group is trans to the $\mathrm{N}$ atom. ${ }^{17}$

In Table 2, the Sn1-Cl1, Sn1-Cl2 and Sn1-Cl3 distances are given as 2.429(2), 2.399(2) and 2.422(2) ̊̊, respectively. Therefore, the average of the Sn1-Cl1 and $\mathrm{Sn} 1-\mathrm{Cl} 3$ bond lengths ( $\mathrm{Cl}$ trans to the dbso ligand) is $2.426(2) \AA$, and $2.426-2.399=0.027 \AA$. The O-Sn-O bonds [2.203(5) and 2.241(7) $\AA$ ] form an angle of $92.6(3)^{\circ}$ at the metal and the S-O bonds lengths [1.523(8) and 1.522(5) $\AA$ ] are otherwise not much different from those bonds observed in other mono-organotin(IV) adducts containing sulfoxide as ligand. ${ }^{16,17}$ The $[\mathrm{Sn}-\mathrm{C} 2.142(8) \AA]$ bond distance is longer than those found in $\operatorname{mer}$-[ $\left.\mathrm{MeSnCl}_{3}(\mathrm{ImSOMe})\right]$ [2.122(4) $\AA$ ] and in $m e r-\left[\mathrm{MeSnCl}_{3}\left(\mathrm{PySO}{ }^{n} \mathrm{Pr}\right)\right][2.110(7) \AA]$, but it is shorter than the $\mathrm{Sn}-\mathrm{C}$ [2.218(5) $\mathrm{A}]$ found in mer$\left[\mathrm{EtSnI}_{3}(\mathrm{dpso})_{2}\right]{ }^{16}$ 
Table 1. Crystal data and structure refinement

\begin{tabular}{|c|c|c|}
\hline Compound & trans $-\left[\mathrm{Ph}_{2} \mathrm{SnCl}_{2}(\mathrm{dbso})_{2}\right]$ & $\mathrm{fac}-\left[\mathrm{MeSnCl}_{3}(\mathrm{dbso})_{2}\right]$ \\
\hline Empirical formula & $\mathrm{C}_{40} \mathrm{H}_{38} \mathrm{Cl}_{2} \mathrm{O}_{2} \mathrm{~S}_{2} \mathrm{Sn}$ & $\mathrm{C}_{29} \mathrm{H}_{31} \mathrm{Cl}_{3} \mathrm{O}_{2} \mathrm{~S}_{2} \mathrm{Sn}$ \\
\hline Formula weight & 804.45 & 700.98 \\
\hline Temperature (K) & $100(2)$ & $297(2)$ \\
\hline Wavelength $(\AA)$ & 0.71073 & 1.54180 \\
\hline Crystal system & Orthorhombic & Monoclinic \\
\hline Space group & Pbcn & $P 2_{1} / c$ \\
\hline Crystal color/habit & Colourless/prism & Colourless/prism \\
\hline$a(\AA)$ & $14.347(1)$ & $9.182(4)$ \\
\hline$b(\AA)$ & $10.259(1)$ & $19.281(4)$ \\
\hline$c(\AA)$ & $23.661(1)$ & $18.057(5)$ \\
\hline$\beta$ (deg.) & & $104.44(2)$ \\
\hline Volume $\left(\AA^{3}\right)$ & $3482.6(4)$ & $3095.7(17)$ \\
\hline$Z$ & 4 & 4 \\
\hline $\begin{array}{l}\text { Calculated density } \\
\left(\mathrm{g} \mathrm{cm}^{-3}\right)\end{array}$ & 1.534 & 1.503 \\
\hline \multicolumn{2}{|c|}{$\begin{array}{l}\text { Absorption coefficient } 1.043 \\
\left(\mathrm{~mm}^{-1}\right)\end{array}$} & 1.041 \\
\hline Crystal size (mm) & $0.15 \times 0.10 \times 0.06$ & $0.40 \times 0.20 \times 0.20$ \\
\hline $\begin{array}{l}\text { Theta range for data } \\
\text { collection }\left({ }^{\circ}\right)\end{array}$ & 2.23 to 27.85 & 3.41 to 68.04 \\
\hline Index ranges & $\begin{array}{l}-18 \leq h \leq 18 \\
-13 \leq k \leq 0 \\
0 \leq l \leq 30\end{array}$ & $\begin{array}{l}-11 \leq h \leq 9 \\
-23 \leq k \leq 4 \\
0 \leq l \leq 21\end{array}$ \\
\hline Reflections collected & 7475 & 6420 \\
\hline $\begin{array}{l}\text { Independent } \\
\text { reflections }\end{array}$ & $\begin{array}{l}3953 \\
{[R(\text { int })=0.0462]}\end{array}$ & $\begin{array}{l}5551 \\
{[R(\text { int })=0.0826]}\end{array}$ \\
\hline $\begin{array}{l}\text { Data/restraints/ } \\
\text { parameters }\end{array}$ & $3953 / 0 / 215$ & $5551 / 0 / 294$ \\
\hline Goodness-of-fit on $F^{2}$ & 1.132 & 1.045 \\
\hline $\begin{array}{l}\text { Final } R \text { indices } \\
{[I>2 \sigma(I)]}\end{array}$ & $\begin{array}{l}R_{1}=0.0530 \\
w R_{2}=0.1659\end{array}$ & $\begin{array}{l}R_{1}=0.0650 \\
w R_{2}=0.1751\end{array}$ \\
\hline$R$ indices (all data) & $\begin{array}{l}R_{1}=0.0901 \\
w R_{2}=0.1906\end{array}$ & $\begin{array}{l}R_{1}=0.1029 \\
w R_{2}=0.1996\end{array}$ \\
\hline Extinction coefficient & $0.0018(4)$ & $0.0008(1)$ \\
\hline $\begin{array}{l}\text { Largest diff. peak and } \\
\text { hole }\left(\mathrm{e} \AA^{-3}\right)\end{array}$ & 1.463 and -1.636 & 1.044 and -1.402 \\
\hline
\end{tabular}

\section{Infrared spectroscopy}

Table 3 lists the most important IR data, allowing several conclusions. The dbso ligand always binds to the tin(IV) moiety through the oxygen atom, as shown by the shift of $v(\mathrm{~S}-\mathrm{O})$ to lower values as compared to the free base. The $v(\mathrm{Sn}-\mathrm{O})$ bands appear at $483 \mathrm{~cm}^{-1}$ for $\mathrm{fac}$-[ $\left.\mathrm{MeSnCl}_{3}(\mathrm{dbso})_{2}\right]$, at $460 \mathrm{~cm}^{-1}$ for trans $-\left[\mathrm{Ph}_{2} \mathrm{SnCl}_{2}(\mathrm{dbso})_{2}\right]$ and at $455 \mathrm{~cm}^{-1}$ for $\left[\mathrm{Ph}_{3} \mathrm{SnCl}(\mathrm{dbso})\right]$, in accordance with reported work related to ambidentate sulfoxides bonded to tin(IV). ${ }^{18}$ However, the $v(\mathrm{Sn}-\mathrm{O})$ absorptions in five-coordinate diorganotin(IV)-

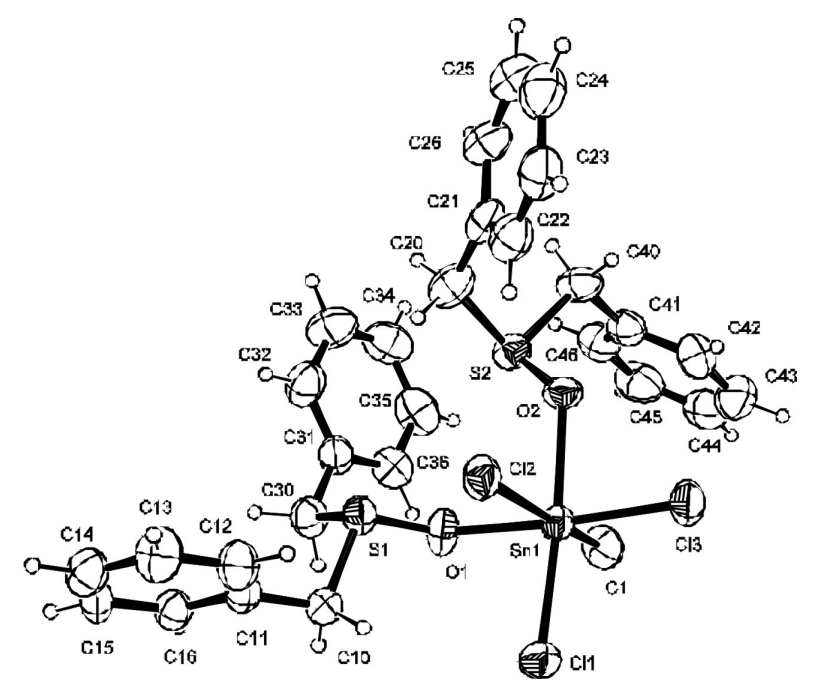

Figure 1. View of $f a c$ - $\left[\mathrm{MeSnCl}_{3}(\mathrm{dbso})_{2}\right]$ with the displacement parameters drawn at the $30 \%$ probability level.

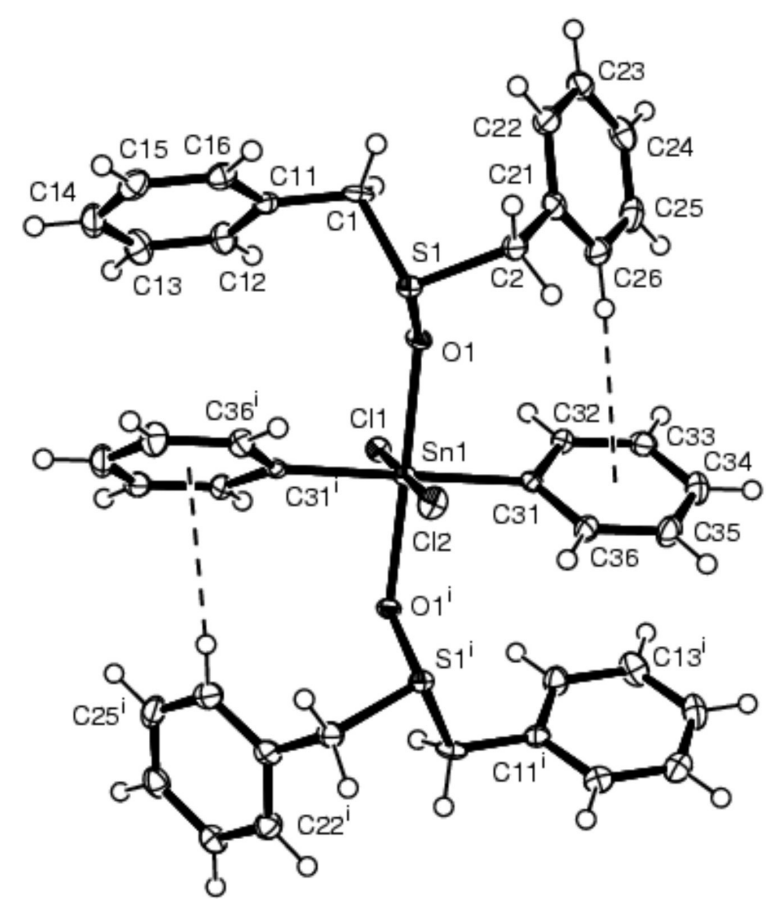

Figure 2. View of trans- $\left[\mathrm{Ph}_{2} \mathrm{SnCl}_{2}(\mathrm{dbso})_{2}\right]$, with ellipsoids drawn at the $50 \%$ probability level and hydrogen atoms as spheres of arbitrary radii. The dashed lines indicate intramolecular $\mathrm{C}-\mathrm{H} \cdots \pi$ contacts. [Symmetry code: (i) $-x+1, y,-z+1 / 2]$.

sulfoxide adducts have been reported in the $415-440 \mathrm{~cm}^{-1}$ range. ${ }^{19}$ The $v(\mathrm{C}=\mathrm{C}), \delta(\mathrm{C}-\mathrm{H})$ and $\delta(\mathrm{C}=\mathrm{C})$ stretching vibrations do not show any appreciable alteration, indicating that the benzyl groups are far from the coordination center.

$\left({ }^{1} \mathrm{H},{ }^{13} \mathrm{C},{ }^{119} \mathrm{Sn}\right) \mathrm{NMR}$ spectroscopy

The assignment of the ${ }^{1} \mathrm{H}$ and ${ }^{13} \mathrm{C}$ chemical shifts is presented in the experimental section, and coupling 
constants, ${ }^{1} J\left({ }^{119} \mathrm{Sn}-{ }^{13} \mathrm{C}\right)$ and ${ }^{2} J\left({ }^{119} \mathrm{Sn}-{ }^{1} \mathrm{H}\right)$, and chemical shifts, $\delta\left({ }^{119} \mathrm{Sn}\right)$, of our adducts, as well as of other compounds from the literature, are shown in Table 4. The NMR coupling constants ${ }^{1} J\left({ }^{119} \mathrm{Sn}-{ }^{13} \mathrm{C}\right)$ and ${ }^{2} J\left({ }^{119} \mathrm{Sn}-{ }^{1} \mathrm{H}\right)$ for compound $\mathbf{5}$, which was crystallographically characterized $^{5}$ as being a five-coordinate tin(IV) adduct, were observed at 568 and $72 \mathrm{~Hz}$, respectively. However, the adduct $\mathbf{6}$, which has higher coupling constants values of 888 and $92 \mathrm{~Hz}$, is formed by six-coordinate tin(IV) atoms. In view of this, the coupling constants values for adducts 1-3 indicate that, in $\mathrm{CDCl}_{3}$ solution, they are no longer octahedral as in the solid state, but undergo a structural

Table 2. Selected bond lengths $[\AA]$ and angles $\left[{ }^{\circ}\right]$

\begin{tabular}{|c|c|c|c|}
\hline \multicolumn{2}{|c|}{ trans $-\left[\mathrm{Ph}_{2} \mathrm{SnCl}_{2}(\mathrm{dbso})_{2}\right]$} & \multicolumn{2}{|c|}{$\mathrm{fac}-\left[\mathrm{MeSnCl}_{3}(\mathrm{dbso})_{2}\right]$} \\
\hline Sn1-C31 & $2.147(6)$ & Sn1-C1 & $2.142(8)$ \\
\hline Sn1-O1 & $2.258(4)$ & Sn1-O1 & $2.203(5)$ \\
\hline $\mathrm{Sn} 1-\mathrm{Cl} 2$ & $2.509(2)$ & $\mathrm{Sn} 1-\mathrm{O} 2$ & $2.241(7)$ \\
\hline Sn1-Cl1 & $2.578(2)$ & Sn1-Cl1 & $2.429(2)$ \\
\hline Sn1-O1 & $2.258(4)$ & $\mathrm{Sn} 1-\mathrm{Cl} 2$ & $2.399(2)$ \\
\hline $\mathrm{S} 1-\mathrm{O} 1$ & $1.524(4)$ & $\mathrm{Sn} 1-\mathrm{Cl} 3$ & $2.422(2)$ \\
\hline $\mathrm{S} 1-\mathrm{C} 1$ & $1.815(5)$ & $\mathrm{S} 1-\mathrm{O} 1$ & $1.529(5)$ \\
\hline $\mathrm{S} 1-\mathrm{C} 2$ & $1.829(5)$ & $\mathrm{S} 2-\mathrm{O} 2$ & $1.523(8)$ \\
\hline C $31-S n 1-C 31^{\mathrm{i}}$ & 177.3(3) & $\mathrm{C} 1-\mathrm{Sn} 1-\mathrm{Cl} 3$ & $96.4(3)$ \\
\hline $\mathrm{C} 31-\mathrm{Sn} 1-\mathrm{O} 1^{\mathrm{i}}$ & $91.5(2)$ & $\mathrm{O} 1-\mathrm{Sn} 1-\mathrm{Cl} 3$ & $175.8(2)$ \\
\hline C31-Sn1-O1 & $88.3(2)$ & $\mathrm{O} 2-\mathrm{Sn} 1-\mathrm{C} 13$ & $83.7(2)$ \\
\hline $\mathrm{O} 1^{\mathrm{i}}-\mathrm{Sn} 1-\mathrm{O} 1$ & $174.0(2)$ & $\mathrm{Cl} 2-\mathrm{Sn} 1-\mathrm{Cl} 3$ & $92.43(8)$ \\
\hline $\mathrm{C} 31-\mathrm{Sn} 1-\mathrm{Cl} 2$ & $91.4(1)$ & $\mathrm{C} 1-\mathrm{Sn} 1-\mathrm{Cl1}$ & $99.0(3)$ \\
\hline $\mathrm{O} 1-\mathrm{Sn} 1-\mathrm{Cl} 2$ & $93.0(1)$ & O1-Sn1-Cl1 & $88.3(2)$ \\
\hline C31-Sn1-C11 & $88.6(1)$ & $\mathrm{O} 2-\mathrm{Sn} 1-\mathrm{Cl} 1$ & $168.0(2)$ \\
\hline O1-Sn1-Cl1 & $87.0(1)$ & $\mathrm{C} 1-\mathrm{Sn} 1-\mathrm{O} 1$ & $85.6(3)$ \\
\hline $\mathrm{O} 1-\mathrm{S} 1-\mathrm{C} 1$ & $103.0(2)$ & $\mathrm{Cl} 2-\mathrm{Sn} 1-\mathrm{Cl} 1$ & $88.07(8)$ \\
\hline $\mathrm{O} 1-\mathrm{S} 1-\mathrm{C} 2$ & $105.7(2)$ & $\mathrm{C} 1-\mathrm{Sn} 1-\mathrm{O} 2$ & $93.0(3)$ \\
\hline $\mathrm{C} 1-\mathrm{S} 1-\mathrm{C} 2$ & 101.5(3) & $\mathrm{Cl} 3-\mathrm{Sn} 1-\mathrm{Cl} 1$ & $95.00(9)$ \\
\hline
\end{tabular}

Symmetry code: (i) $-\mathrm{x}+1, \mathrm{y},-\mathrm{z}+1 / 2$. change, showing five-coordinate behavior. In addition to that, the coupling constants for adduct 7 are considerably larger than those for adducts $\mathbf{1 - 5}$, indicating that higher ${ }^{1} J\left({ }^{119} \mathrm{Sn}-{ }^{13} \mathrm{C}\right)$ and ${ }^{2} J\left({ }^{19} \mathrm{Sn}-{ }^{1} \mathrm{H}\right)$ values tend to correlate with higher coordination numbers (see Table 4). This can be attributed, at least partially, to a tendency to maximize the $s$-character in the $\mathrm{C}-\mathrm{Sn}-\mathrm{C}$ bonds in six-coordinate derivatives. ${ }^{20}$ Applying the equation ${ }^{1} J\left({ }^{119} \mathrm{Sn}-{ }^{13} \mathrm{C}\right)=$ $11.4 \theta-875$, and our observed coupling constant of $568 \mathrm{~Hz}$ to adduct $\mathbf{5}$, whose X-ray structure is known, we find the value of $127^{\circ}$ for the (C-Sn-C) angle $\theta$ of adduct $\mathbf{5}$, only $9^{\circ}$ lower than the angle of $136.4(9)^{\circ}$ reported by $\mathrm{Ng}$ and Rheingold ${ }^{4}$ (Table 4). The NMR data for the 1:1 adduct $\left[\mathrm{Me}_{2} \mathrm{SnCl}_{2}(\mathrm{Hmimt})\right][\mathrm{Hmimt}=1$-methyl-2(3H)imidazolinethione], whose X-ray structure shows it to be a trigonal bipyramid, ${ }^{21}$ present some similarity with the data for adduct 5. The reported values of ${ }^{1} J\left({ }^{119} \mathrm{Sn}-{ }^{13} \mathrm{C}\right)$, ${ }^{2} J\left({ }^{119} \mathrm{Sn}-{ }^{1} \mathrm{H}\right), \delta\left({ }^{119} \mathrm{Sn}\right)$ and $\theta(\mathrm{C}-\mathrm{Sn}-\mathrm{C})$ for this compound are $491,71 \mathrm{~Hz},+19 \mathrm{ppm}$ and $133^{\circ}$, respectively.

The coupling constant ${ }^{2} J\left({ }^{119} \mathrm{Sn}-{ }^{1} \mathrm{H}\right)$ value of $123 \mathrm{~Hz}$ found for $\mathrm{fac}$-adduct $\mathbf{1 8}$ is only $8 \mathrm{~Hz}$ higher than that found for $f a c$-adduct $\mathbf{1 6}$ and it is almost equal to that of $124 \mathrm{~Hz}$ found for mer-adduct $\mathbf{1 7}$. This observation indicates that this behavior may be due more to an electronic rather than to a structural effect, wherein the oxygen atom in BtSOMe exhibits a higher electronic donor effect than the oxygen in dbso. Thus the tin(IV) atom would be more shielded in $\mathbf{1 8}$ than in 16. This behaviour is also observed in ${ }^{119} \mathrm{Sn}$-NMR spectroscopy.

${ }^{119} \mathrm{Sn}$ chemical shifts were found to lie between ca. -90 and $-330 \mathrm{ppm}$ in five-coordinate dimethyltin(IV) chelates. ${ }^{22}$ However, the values for adducts 1-5 (Table 4) are completely out of this range, indicating that the presence of chlorine atoms in the coordination sphere of the tin(IV) nucleus shifts the signal towards much more deshielded values. In diphenyltin(IV) derivatives, (adducts 8-10 and 12), the chemical shift values were found as usual, i.e., at lower frequencies than in dimethyltin(IV) adducts, in spite

Table 3. Selected infrared absorptions $\left(\mathrm{cm}^{-1}\right)$

\begin{tabular}{|c|c|c|c|c|c|c|c|}
\hline Compound & C.N. & $v(C=C)$ & $v(\mathrm{~S}=\mathrm{O})$ & $\Delta v(\mathrm{~S}=\mathrm{O})$ & $v(\mathrm{Sn}-\mathrm{O})$ & $\delta(\mathrm{C}-\mathrm{H})$ & $\delta(\mathrm{C}=\mathrm{C})$ \\
\hline dbso & - & $1493 \mathrm{vs}, 1455 \mathrm{vs}$ & $1033 \mathrm{vs}$ & - & - & 776vs & $700 \mathrm{vs}$ \\
\hline$\left[\mathrm{Me}_{2} \mathrm{SnCl}_{2} \cdot \mathrm{dbso}\right]^{\mathrm{a}}$ & 5 & 1496vs, 1458vs & 988vs & 45 & - & $775 \mathrm{sh}$ & $697 \mathrm{vs}$ \\
\hline$\left[\mathrm{Ph}_{2} \mathrm{SnCl}_{2} \cdot(\mathrm{dbso})_{2}\right]^{\mathrm{b}}$ & 6 & $1494 \mathrm{~s}, 1455 \mathrm{~s}$ & $984 v s$ & 49 & $460 \mathrm{~s}$ & 776vs & $700 \mathrm{vs}$ \\
\hline$\left[{ }^{n} \mathrm{Bu}_{2} \mathrm{SnCl}_{2} \cdot \mathrm{dbso}\right]_{2}$ & 6 & 1494vs, 1455vs & $973 v s$ & 60 & - & $776 v s$ & 701vs \\
\hline$\left[\mathrm{MeSnCl}_{3} \cdot(\mathrm{dbso})_{2}\right]^{\mathrm{a}}$ & 6 & $1496 \mathrm{vs}, 1455 \mathrm{vs}$ & $950 \mathrm{vs}$ & 83 & $483 \mathrm{~s}$ & $767 \mathrm{vs}$ & $697 \mathrm{vs}$ \\
\hline$\left[\mathrm{Ph}_{3} \mathrm{SnCl}_{2} \cdot \mathrm{dbso}\right]^{\mathrm{c}}$ & 5 & $1492 \mathrm{~s}, 1452 \mathrm{~s}$ & $969 \mathrm{vs}$ & 64 & $455 \mathrm{~s}$ & $775 \mathrm{vs}$ & $698 \mathrm{vs}$ \\
\hline
\end{tabular}

Abbreviations and attributions: C.N. = coordination number; ${ }^{a} v_{\mathrm{a}}\left(\mathrm{Sn}-\mathrm{CH}_{3}\right)=572 \mathrm{~m} \mathrm{~cm}^{-1} ; v_{\mathrm{s}}\left(\mathrm{Sn}-\mathrm{CH}_{3}\right)=516 \mathrm{~m} \mathrm{~cm}{ }^{-1} ;{ }^{b} v(\mathrm{C}=\mathrm{C})=1480 \mathrm{~s} ; 1430 \mathrm{~s} \mathrm{~cm}{ }^{-1}(\mathrm{Sn}-\mathrm{Ph})$; ${ }^{c} \mathrm{v}(\mathrm{C}=\mathrm{C})=1478 \mathrm{~s}, 1429 \mathrm{~s} \mathrm{~cm}{ }^{-1}(\mathrm{Sn}-\mathrm{Ph}) ; \mathrm{v}=$ stretching; s = strong; vs = very strong; sh = shoulder; m = medium; $\delta=$ out of plane deformation. 
of the greater electron donation properties of the methyl groups compared to phenyl. ${ }^{23}$ This observed dependence of the chemical shift of the tin(IV) atom on the nature of the diorganotin(IV) derivative can be related to the relative polarity of the $\mathrm{Sn}-\mathrm{C}$ bonds. The polarity of these bonds depends on the amount of residual positive charge located on tin, as well as on the s-character of tin(IV) in these bonds. ${ }^{24}$ Accordingly, more residual positive charge is localized on the central tin(IV) atom in $\mathrm{Ph}_{2} \mathrm{Sn}^{2+}$ compared to $\mathrm{Me}_{2} \mathrm{Sn}^{2+}$. Therefore, more shielding is expected on the tin(IV) atom in the five-coordinate diphenyltin(IV) derivative. The ${ }^{119} \mathrm{Sn}$ chemical shift value of $-167 \mathrm{ppm}$, observed for adduct $\mathbf{1 4}$, is inside the range of -125 to -515 ppm observed for six-coordinate diorganotin(IV) chelates. ${ }^{22}$

\section{Mössbauer spectroscopy}

${ }^{119} \mathrm{Sn}$ Mössbauer spectral parameters of the dbso derivatives are reported in Table 5, which includes parameters from the literature for comparison. The spectra of the adducts 2, 7, 13 and $\mathbf{1 9}$ are shown in Figure 3.

The isomer shift $(\delta)$ is very sensitive to the first coordination sphere and depends on the nature and number of organic groups bonded to the tin(IV) atom..$^{28,29}$ This parameter is correlated to the change of $s$-electron density on the metal by means of the $+\mathrm{I}$ inductive effect imposed by the ligands. A result of this is the inverse dependence of $\delta$ with electronegativity. ${ }^{30}$ Thus $\delta$ increases on replacing the phenyl by the alkyl groups in the coordination sphere of tin(IV). This increase in $\delta$ can be seen (Table 5) starting with the adducts 17-20 derived from $\mathrm{MeSnCl}_{3}(0.89-0.97$ $\mathrm{mm} \mathrm{s}^{-1}$ ), including the adducts 12-16 derived from $\mathrm{Ph}_{2} \mathrm{SnCl}_{2}$ (1.26-1.39 $\left.\mathrm{mm} \mathrm{s}^{-1}\right)$, and finishing with the adducts 1-6 derived from $\mathrm{Me}_{2} \mathrm{SnCl}_{2}\left(1.35-1.47 \mathrm{~mm} \mathrm{~s}^{-1}\right)$. The adduct 7 derived from ${ }^{n} \mathrm{Bu}_{2} \mathrm{SnCl}_{2}\left(1.63 \mathrm{~mm} \mathrm{~s}^{-1}\right)$ confirms that isomer shifts increase in the sequence $\mathrm{Ph}_{2} \mathrm{Sn}^{2+}<\mathrm{Me}_{2} \mathrm{Sn}^{2+}<{ }^{n} \mathrm{Bu}_{2} \mathrm{Sn}^{2+}$ (see Table 5).

The quadrupole splitting $(\Delta)$ values summarized in Table 5 show that this parameter can potentially throw light upon the question of which is the correct coordination number of the tin(IV) atom in adducts formed from diorganotin(IV) dichloride and monodentate ligands. The $\Delta$ value of adduct $\mathbf{1}\left(3.52 \mathrm{~mm} \mathrm{~s}^{-1}\right)$ is typical of dimethyltin(IV) adducts with a distorted trigonal bypyramidal geometry around the tin(IV) atom, as supported by the crystal structure determination: an authentic five-coordinate trigonal bipyramidal compound ${ }^{5}$

Table 4. $\left({ }^{1} \mathrm{H},{ }^{13} \mathrm{C}\right)$-NMR coupling constants $(J, \mathrm{~Hz})$ and ${ }^{119} \mathrm{Sn}$-NMR chemical shifts $(\delta$, ppm)

\begin{tabular}{|c|c|c|c|c|}
\hline Adduct & C.N. & ${ }^{2} J\left({ }^{119} \mathrm{Sn}-{ }^{1} \mathrm{H}\right)$ & ${ }^{1} J\left({ }^{119} \mathrm{Sn}-{ }^{13} \mathrm{C}\right)$ & $\delta\left({ }^{119} \mathrm{Sn}\right)$ \\
\hline 1. $\left[\mathrm{Me}_{2} \mathrm{SnCl}_{2}\left({ }^{n} \mathrm{PrSOCH}_{2}\right)_{2}\right]^{\mathrm{a}}$ & $5,6^{\mathrm{h}}$ & 78 & 595 & +9 \\
\hline 2. $\left[\left\{{ }^{n} \mathrm{Bu}_{2} \mathrm{SnCl}_{2}(\mathrm{dbso})\right\}_{2}\right]^{\mathrm{b}}$ & $5,6^{\mathrm{h}}$ & - & - & +42 \\
\hline 3. $\left[\left\{\mathrm{Me}_{2} \mathrm{SnCl}_{2}\left(\mathrm{PhSOCH}_{2}\right)_{2}\right\}_{n}\right]^{\mathrm{a}}$ & $5,6^{\mathrm{h}}$ & 71 & - & +59 \\
\hline 4. $\left[\mathrm{Me}_{2} \mathrm{SnCl}_{2}(\mathrm{BtSOMe})\right]^{\mathrm{c}}$ & 5 & 72 & 538 & +99 \\
\hline 5. $\left[\mathrm{Me}_{2} \mathrm{SnCl}_{2}(\mathrm{dbso})\right]^{\mathrm{b}}$ & 5 & 72 & 568 & +100 \\
\hline 6. trans- $\left[\mathrm{Me}_{2} \mathrm{SnCl}_{2}(\mathrm{ImSOMe})\right]^{\mathrm{d}}$ & 6 & 92 & 888 & -8 \\
\hline 7. trans $-\left[\mathrm{Me}_{2} \mathrm{SnCl}_{2}(\mathrm{dmso})_{2}\right]^{\mathrm{e}}$ & 6 & 86 & 1060 & - \\
\hline 8. $\left[\mathrm{Ph}_{2} \mathrm{SnCl}_{2}(\mathrm{ImSOMe})\right]^{\mathrm{d}}$ & 5 & - & - & -36 \\
\hline 9. $\left[\mathrm{Ph}_{2} \mathrm{SnCl}_{2}\left\{\left(\mathrm{CH}_{2}\right)_{3} \mathrm{SOCH}(\mathrm{Ph}) \mathrm{SO}\right\}\right]^{\mathrm{f}}$ & 5 & - & - & -62 \\
\hline 10. $\left[\mathrm{Ph}_{2} \mathrm{SnCl}_{2}(\mathrm{BtSOMe})\right]^{\mathrm{c}}$ & 5 & - & - & -63 \\
\hline 11. $\left[\mathrm{Ph}_{3} \mathrm{SnCl}(\mathrm{dbso})\right]^{\mathrm{b}}$ & 5 & - & - & -67 \\
\hline 12. $\left[\mathrm{Ph}_{2} \mathrm{SnCl}_{2}\left(\mathrm{PySO}{ }^{n} \mathrm{Pr}\right)\right]^{\mathrm{g}}$ & 5 & - & - & -108 \\
\hline 13. trans $-\left[\left\{\mathrm{Ph}_{2} \mathrm{SnCl}_{2}\left(\mathrm{PhSOCH}_{2}\right)_{2}\right\}_{n}\right]^{\mathrm{a}}$ & 6 & - & - & -129 \\
\hline 14. trans $-\left[\mathrm{Ph}_{2} \mathrm{SnCl}_{2}(\mathrm{dbso})_{2}\right]^{\mathrm{b}}$ & 6 & - & - & -167 \\
\hline 15. $\left[\left\{\mathrm{Ph}_{2} \mathrm{SnCl}_{2}\left({ }^{n} \mathrm{PrSOCH}_{2}\right)_{2}\right\}_{n}\right]^{\mathrm{a}}$ & 6 & - & - & -168 \\
\hline 16. $f a c-\left[\mathrm{MeSnCl}_{3}(\mathrm{BtSOMe})_{2}\right]^{\mathrm{c}}$ & 6 & 115 & 538 & -214 \\
\hline 17. $m e r-\left[\mathrm{MeSnCl}_{3}\left(\mathrm{PySO}^{n} \mathrm{Pr}\right)\right]^{\mathrm{g}}$ & 6 & 124 & - & -350 \\
\hline 18. $f a c-\left[\mathrm{MeSnCl}_{3}(\mathrm{dbso})_{2}\right]^{\mathrm{b}}$ & 6 & 123 & - & -368 \\
\hline
\end{tabular}

Abbreviations and attributions: C.N. = coordination number; BtSOMe = 2-(methylsulfinyl)benzothiazole; ImSOMe = 1-methyl-2-(methylsulfinyl)imidazole; $\left(\mathrm{CH}_{2}\right)_{3} \mathrm{SOCH}(\mathrm{Ph}) \mathrm{SO}=2$-phenyl-1,3-dithiane-trans-1-trans-3-dioxide; $\mathrm{PySO}^{n} \mathrm{Pr}=2$ - $(n$-propylsulfinyl $)$ pyridine; dmso = dimethylsulfoxide; ${ }^{\mathrm{a}}$ reference 25 ;

${ }^{\mathrm{b}}$ this work; ${ }^{\mathrm{c}}$ reference $19 ;{ }^{\mathrm{d}}$ reference $26 ;{ }^{\mathrm{e}}$ reference $27 ;{ }^{\mathrm{f}}$ reference $6 ;{ }^{\mathrm{g}}$ reference $26 ;{ }^{\mathrm{h}}$ Coordination number in solid state. 
without any short intermolecular contact. The parameters $\delta=1.45 ; \Delta=3.13 \mathrm{~mm} \mathrm{~s}^{-1}$ and the angle $\theta(\mathrm{C}-\mathrm{Sn}-\mathrm{C})=133^{\circ}$ have been reported for the related adduct with analogous coordination geometry, namely $\left[\mathrm{Me}_{2} \mathrm{SnBr}_{2}(\mathrm{Hmimt})\right] .{ }^{21}$ The larger $\Delta$ value of adduct $2\left(3.84 \mathrm{~mm} \mathrm{~s}^{-1}\right)$, compared to $\mathbf{1}\left(3.52 \mathrm{~mm} \mathrm{~s}^{-1}\right)$, is due to the considerable intermolecular contact $[\mathrm{S}=\mathrm{O} \cdots \mathrm{Sn} 2.75(1) \AA]$, which makes this distance much shorter than the sum of the van der Waals ${ }^{31}$ radii of the two atoms, $r_{\mathrm{Sn}}=2.2, r_{\mathrm{o}}=1.5 \AA$. Thus, the $\mathrm{C}-\mathrm{Sn}-\mathrm{C}$ angle is opened up to $154.7(3)^{\circ}$, to complete the distorted trans-C-Sn-C skeleton. ${ }^{16}$ The differences observed in $\Delta$ values ranging from 3.54-4.16 $\mathrm{mm} \mathrm{s}^{-1}$ for adducts 4-7, compared to adducts $\mathbf{1}$ and $\mathbf{3}$, are considerable (Table 5). Therefore, this means that these compounds (4-7) possess the same geometry around the tin(IV) atom, which corresponds to six-coordinated structures, as supported by X-ray diffraction for $\mathbf{4},{ }^{19} \mathbf{5},{ }^{32}$ and $\mathbf{6} \cdot{ }^{33}$ In view of this, the Mössbauer spectra of the adducts 8-11 show a doublet with values of $\Delta$ ranging from 2.92-3.22 $\mathrm{mm} \mathrm{s}^{-1}$, indicating five-coordinated tin(IV) compounds, whereas the spectra of 12-16 show values ranging from
$3.51-3.98 \mathrm{~mm} \mathrm{~s}^{-1}$, which are typical of six-coordinated tin(IV) derivatives.

The geometry about tin(IV) in adducts $\mathbf{1 7}\left(\Delta=2.13 \mathrm{~mm} \mathrm{~s}^{-1}\right)$ and $18\left(\Delta=2.07 \mathrm{~mm} \mathrm{~s}^{-1}\right)$ is that of a distorted octahedron environment, with the $\mathrm{SnCl}_{3}{ }^{+}$skeleton arranged in facial mode (Figure 1). On the other hand, in the octahedral adducts $19\left(\Delta=1.95 \mathrm{~mm} \mathrm{~s}^{-1}\right)$ and $\mathbf{2 0}\left(\Delta=1.69 \mathrm{~mm} \mathrm{~s}^{-1}\right)$, the $\mathrm{SnCl}_{3}^{+}$ skeleton is organized in a meridional position with the methyl group trans to the nitrogen atom in both compounds. ${ }^{17}$ In view of this, we believe that the magnitude of $\Delta$ can be used to distinguish between fac- and mer-arrangements as more crystallographic data become available.

From the $\Delta$ value and the point-charge approach, the equation $\Delta=-4[R]\left(1-0.75 \sin ^{2} \theta\right)^{1 / 2}$ gives an estimate of $\theta$, where $(\theta$, deg $)$ is the $\mathrm{C}-\mathrm{Sn}-\mathrm{C}$ bond angle ${ }^{34}$ and $[\mathrm{R}]$ is the partial quadrupole splitting (pqs) of the group, arising either from the alkyl or the aryl groups. For five- and sixcoordinated tin(IV), the working values used for [Me] and $[\mathrm{Ph}]$ were -1.13 and $-0.95 \mathrm{~mm} \mathrm{~s}^{-1}$, respectively. ${ }^{34,35}$ The calculated bond angle values of $134^{\circ}$ for $\mathbf{1}$ and $180^{\circ}$ for $\mathbf{1 2}$ reveal trigonal bipyramidal (TBP) and

Table 5. Mössbauer data and $\mathrm{C}-\mathrm{Sn}-\mathrm{C}$ angles $\left({ }^{\circ}\right)$

\begin{tabular}{|c|c|c|c|c|}
\hline Adduct & C.N. & $\delta\left(\mathrm{mm} \mathrm{s}^{-1}\right)$ & $\Delta\left(\mathrm{mm} \mathrm{s}^{-1}\right)$ & $\mathrm{C}-\mathrm{Sn}-\mathrm{C}$ (exp.) \\
\hline 1. $\left[\mathrm{Me}_{2} \mathrm{SnCl}_{2}(\mathrm{dbso})\right]^{a}$ & 5 & 1.38 & 3.52 & $136.4(9)^{h}$ \\
\hline 2. $\left[\mathrm{Me}_{2} \mathrm{SnCl}_{2}(\mathrm{ImSOMe})\right]^{b}$ & 5 & 1.47 & 3.84 & $154.7(3)^{i}$ \\
\hline 3. $\left[\mathrm{Me}_{2} \mathrm{SnCl}_{2}(\mathrm{BtSOMe})\right]^{c}$ & 5 & 1.39 & 3.52 & - \\
\hline 4. trans $-\left[\mathrm{Me}_{2} \mathrm{SnCl}_{2}(\mathrm{dmso})_{2}\right]^{d}$ & 6 & 1.40 & 4.16 & $170(2)^{j}$ \\
\hline 5. trans $-\left[\left\{\mathrm{Me}_{2} \mathrm{SnCl}_{2}\left({ }^{n} \mathrm{PrSOCH}_{2}\right)_{2}\right\}_{n}\right]^{e}$ & 6 & 1.38 & 3.73 & $172.3(2)^{k}$ \\
\hline 6. trans $-\left[\left\{\mathrm{Me}_{2} \mathrm{SnCl}_{2}\left(\mathrm{PhSOCH}_{2}\right)_{2}\right\}_{n}\right]^{e}$ & 6 & 1.35 & 3.54 & $165.2(2)^{l}$ \\
\hline 7. trans $-\left[\left\{{ }^{n} \mathrm{Bu}_{2} \mathrm{SnCl}_{2}(\mathrm{dbso})\right\}_{2}\right]^{a}$ & 6 & 1.63 & 4.06 & - \\
\hline 8. $\left[\mathrm{Ph}_{2} \mathrm{SnCl}_{2}\left\{\left(\mathrm{CH}_{2}\right)_{3} \mathrm{SOCH}(\mathrm{Ph}) \mathrm{SO}\right\}\right]^{f}$ & 5 & 1.32 & 3.22 & 138.6(2) \\
\hline 9. $\left[\mathrm{Ph}_{2} \mathrm{SnCl}_{2}(\mathrm{Bt})\right]^{g}$ & 5 & 1.36 & 2.92 & $132.5(7)$ \\
\hline 10. $\left[\mathrm{Ph}_{2} \mathrm{SnCl}_{2}(\mathrm{BtSOMe})\right]^{c}$ & 5 & 1.27 & 2.97 & - \\
\hline 11. $\left[\mathrm{Ph}_{3} \mathrm{SnCl}(\mathrm{dbso})\right]^{a}$ & 5 & 1.32 & 3.19 & - \\
\hline 12. trans $-\left[\mathrm{Ph}_{2} \mathrm{SnCl}_{2}(\mathrm{dbso})_{2}\right]^{a}$ & 6 & 1.32 & 3.98 & 177.3(3) \\
\hline 13. trans $-\left[\mathrm{Ph}_{2} \mathrm{SnCl}_{2}(\mathrm{dmso})_{2}\right]^{d}$ & 6 & 1.27 & 3.95 & $167.2(2) ; 171.8(2)^{m}$ \\
\hline 14. trans $-\left[\mathrm{Ph}_{2} \mathrm{SnCl}_{2}(\mathrm{ImSOMe})\right]^{b}$ & 6 & 1.26 & 3.51 & - \\
\hline 15. trans $-\left[\left\{\mathrm{Ph}_{2} \mathrm{SnCl}_{2}\left({ }^{n} \mathrm{PrSOCH}_{2}\right)_{2}\right\}_{n}\right]^{e}$ & 6 & 1.39 & 3.63 & - \\
\hline 16. trans $-\left[\left\{\mathrm{Ph}_{2} \mathrm{SnCl}_{2}\left(\mathrm{PhSOCH}_{2}\right)_{2}\right\}_{n}\right]^{e}$ & 6 & 1.28 & 3.73 & - \\
\hline 17. $f a c-\left[\mathrm{MeSnCl}_{3}(\mathrm{dbso})_{2}\right]^{a}$ & 6 & 0.92 & 2.13 & - \\
\hline 18. $f a c-\left[\mathrm{MeSnCl}_{3}(\mathrm{BtSOMe})_{2}\right]^{g}$ & 6 & 0.97 & 2.07 & - \\
\hline 19. $m e r-\left[\mathrm{MeSnCl}_{3}(\mathrm{ImSOMe})\right]^{b}$ & 6 & 0.91 & 1.95 & - \\
\hline 20. $m e r-\left[\mathrm{MeSnCl}_{3}\left(\mathrm{PySOPr}^{n}\right)\right]^{b}$ & 6 & 0.89 & 1.69 & - \\
\hline
\end{tabular}

Abbreviations and attributions: C.N. = coordination number; BtSOMe = 2-(methylsulfinyl)-benzothiazole; ImSOMe = 1-methyl-2-(methylsulfinyl) imidazole; $\left(\mathrm{CH}_{2}\right)_{3} \mathrm{SOCH}(\mathrm{Ph}) \mathrm{SO}=2$-phenyl-1,3-dithiane-trans-1-trans-3-dioxide; $\mathrm{PySO}^{n} \mathrm{Pr}=2$-( -propylsulfinyl)pyridine; dmso = dimethylsulfoxide; ${ }^{\mathrm{a}}$ this work; ${ }^{\mathrm{b}}$ reference $26 ;{ }^{\mathrm{c}}$ reference $19 ;{ }^{\mathrm{d}}$ reference $36 ;{ }^{\mathrm{f}}$ reference $6 ;{ }^{\mathrm{g}}$ reference $37 ;{ }^{\mathrm{h}}$ reference $5 ;{ }^{\mathrm{i}}$ reference $16 ;{ }^{\mathrm{j}}$ reference $38 ;{ }^{\mathrm{k}}$ reference $32 ;{ }^{1}$ reference $33 ;{ }^{\mathrm{m}}$ reference 14 . 

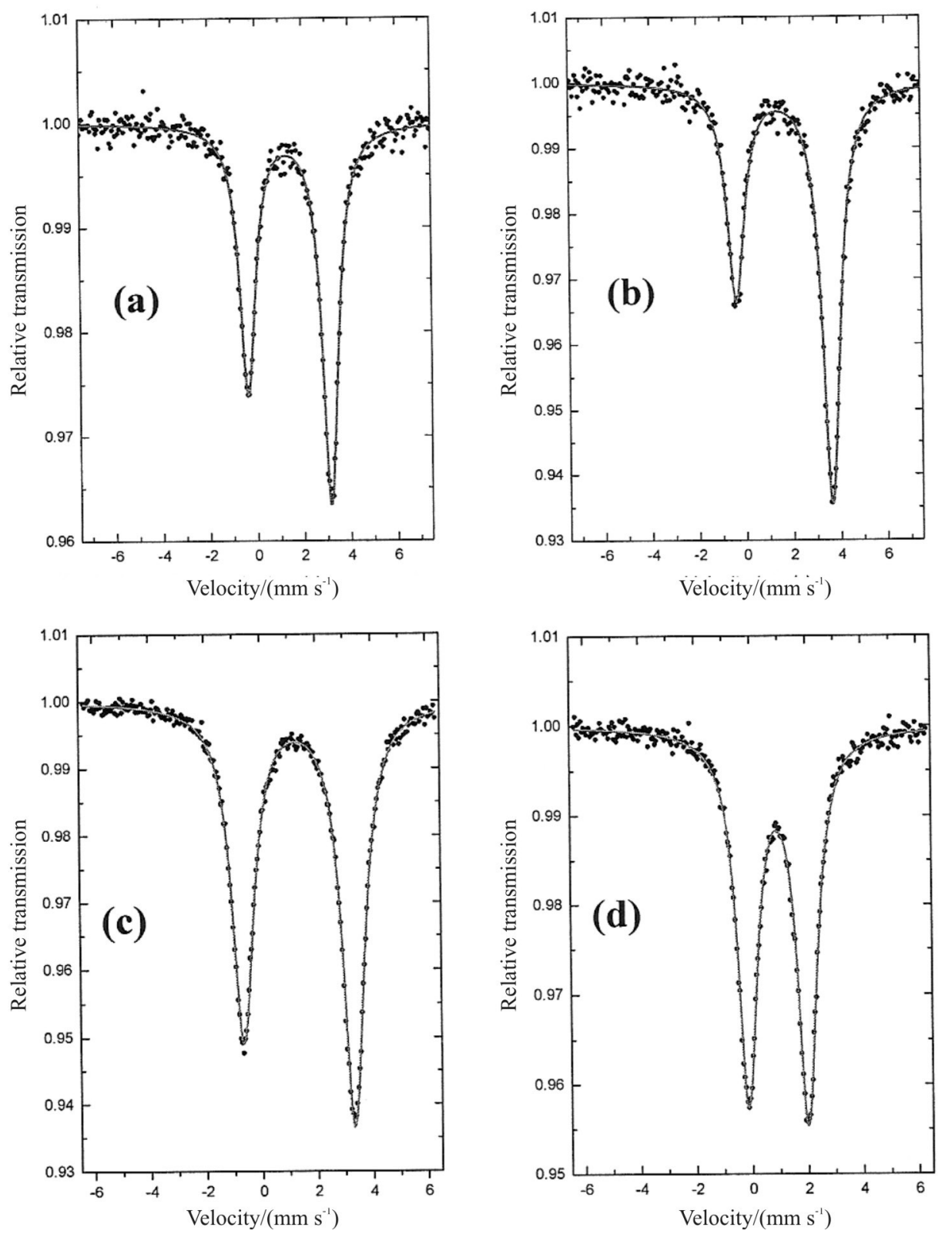

Figure 3. ${ }^{119} \mathrm{Sn}$ Mössbauer effect spectra obtained at $77 \mathrm{~K}$ for complexes $\left[\mathrm{Me}_{2} \mathrm{SnCl}_{2}(\mathrm{dbso})\right](2)-(\mathrm{a}) ;\left[\left\{{ }^{n} \mathrm{Bu}_{2} \mathrm{SnCl}_{2}\left(\mathrm{dbso}_{2}\right\}_{2}\right](7)-(\mathrm{b}) ; \operatorname{trans}\right.$ - $\left[\mathrm{Ph}_{2} \mathrm{SnCl}_{2}\left(\mathrm{dbso}_{2}\right]\right.$ (13)-(c); and $f a c-\left[\mathrm{MeSnCl}_{3}(\mathrm{dbso})_{2}\right]$ (19)-(d).

octahedral $\left(\mathrm{O}_{\mathrm{h}}\right)$ arrangements around the tin(IV) atoms, respectively.

\section{Supplementary Information}

Crystallographic data for the structural analysis of the complexes have been deposited at the Cambridge Crystallographic Data Center, with the deposition numbers CCDC 619271 for trans- $\left[\mathrm{Ph}_{2} \mathrm{SnCl}_{2}(\mathrm{dbso})_{2}\right]$ and CCDC 619272 for $f a c$-[ $\left.\mathrm{MeSnCl}_{3}(\mathrm{dbso})_{2}\right]$. Copies of the data can be obtained free of charge on application to CCDC, 12 Union Road, Cambridge CB21EZ, United Kingdom; Fax: +44 1223 336033, or e-mail: deposit@ccdc.cam.ac.uk.

\section{Acknowledgements}

This work was sponsored by grants from $\mathrm{CNPq}$ and FINEP (CT-INFRA $N^{\circ}$ 0970/01), which are gratefully acknowledged. The author JRS is grateful to the IFSC-USP for providing access to the Kappa CCD diffractometer and cryogenic facilities. 


\section{References}

1. Pellerito, L.; Naggy, L.; Chem. Rev. (Washington, DC, U.S.) 2002, 224, 111.

2. Gielen, M.; Appl. Organomet. Chem. 2002, 16, 481.

3. Gorshkova, J. E.; Gordeliy, V. I.; Crystallogr. Rep. 2007, 52, 535.

4. Ng, S. W.; Barnes, C. L.; van der Helm, D.; Zuckerman, J. J.; Organometallics 1983, 2, 600.

5. Ng, S. W.; Rheingold, A. L.; J. Organomet. Chem. 1989, 378, 339.

6. De Sousa, G. F.; Filgueiras, C. A. L.; Nixon, J. F.; Hitchcock, P. B.; J. Braz. Chem. Soc. 1997, 8, 649.

7. Abras, A.; Filgueiras, C. A. L.; Baba, J. M. K.; J. Inorg. Nucl. Chem. 1981, 43, 2249.

8. Liengme, B. V., Randall, R. S.; Sams, J. R.; Can. J. Chem. 1972, 50, 3212.

9. Enraf-Nonius, COLLECT; Enraf-Nonius BV: Delft, The Netherlands, 1997-2000.

10. Enraf-Nonius, CAD4/PC; Version 1.2. Enraf-Nonius: Delft, The Netherlands, 1993.

11. Harms, K.; Wocadlo, S. XCAD-4; Program for Processing CAD-4 Diffractometer Data, University of Marburg, Germany, 1995.

12. Sheldrick, G .M.; SHELXS97. Program for Crystal Structure Solution, University of Göttingen, Germany, 1997.

13. Sheldrick, G. M.; SHELXL97. Program for Crystal Structure Refinement, University of Göttingen, Germany, 1997.

14. Coghi, L.; Nardelli, M.; Pelizzi, C.; Pelizzi, G.; Gazz. Chim. Ital. 1975, 105, 1187.

15. Karol, T. J.; Hutchinson, J. P.; Hyde, J. R.; Kuivila, H. G.; Zubieta, J. A.; Organometalics 1983, 2, 106.

16. Jatsenko, A. V.; Medvedev, S. V.; Paseshnitchenko, K. A.; Aslanov, L. A.; J. Organomet. Chem. 1985, 284, 181.

17. De Sousa, G. F.; Filgueiras, C. A. L.; Darensbourg, M. Y.; Reibenspies, J. H.; Inorg. Chem. 1992, 31, 3044.

18. Filgueiras, C. A. L.; Celso, C.; Marques, E. V.; Johnson, B. F. G.; Inorg. Chim. Acta 1982, 59, 71.

19. De Sousa, G. F.; Abras, A.; Filgueiras, C. A. L. Proceedings of the International Conference on the Applications of the Mössbauer Effect, ICAME-95, Ortalli, I., Ed., SIF, Bologna, vol. 50, 1996, p. 79.
20. Mcgrady, M. M.; Tobias, R. S.; Inorg. Chem. 1964, 3, 1157.

21. Martínez, E. G.; Gonzáles, A. S.; Casas, J. S.; Sordo, J.; Valle, G.; Russo, U.; J. Organomet. Chem. 1993, 453, 47.

22. Otera, J.; J. Organomet. Chem. 1981, 221, 57.

23. Smith, P. J.; Tupciauskas, A. P.; Ann. Rep. NMR Spectrosc. 1978, 8, 291.

24. Iskander, M. F.; Labib, L.; Nour, M. M. Z.; El-Din, N.; Tawfik, M.; Polyhedron 1989, 8, 2755.

25. De Sousa, G. F.; Filgueiras, C. A. L.; Abras, A.; Carvalho, C. C.; Francisco, R. H. P.; Gambardella, M. T. do P.; Anais Assoc. Bras. Quim. 1995, 44, 42.

26. De Sousa. G. F. Synthesis, Characterization and Reactivity of Organocomplexes of Tin and Platinum: Spectroscopy and X-ray Diffraction, Doctoral Thesis, Universidade Federal de Minas Gerais, Belo Horizonte, Brazil, 1992.

27. Lockart T. P.; Manders W. F.; J. Am. Chem. Soc. 1987, 109, 7015.

28. Carcelli, M.; Fochi, A.; Pellagatti, P.; Pelizzi, G.; Russo, U.; J. Organomet. Chem. 2001, 628, 161.

29. De Sousa, G. F.; Deflon, V. M.; Gambardella, M. T. do P.; Francisco, R. H. P.; Ardisson, J. D.; Niquet, E.; Inorg. Chem. 2006, 45, 4518.

30. Kovala-Demertzi, D.; Kourkounelis, N.; Koutsodimou, A.; Moukarika, A.; Horn, E.; Tiekink, E. R. T.; J. Organomet. Chem. 2001, 620, 194.

31. Huheey, J. E. Inorganic Chemistry-Principles of Structure and Reactivity, $3^{\text {rd }}$ ed., Harper \& Row, New York, 1983.

32. Carvalho, C. C.; Francisco, R. H. P.; Gambardella, M. T. do P.; De Sousa, G. F.; Filgueiras, C. A. L.; Acta Crystallogr., Sect. C: Cryst. Struct. Commun. 1996, 1627.

33. Carvalho, C. C.; Francisco, R. H. P.; Gambardella, M. T. do P.; De Sousa, G. F.; Filgueiras, C. A. L.; Acta Crystallogr., Sect. C: Cryst. Struct. Commun. 1996, 1629.

34. Bancroft, G. M.; Sham, T. K.; Inorg. Chem. 1975, 14, 2281.

35. Jankovics, H.; Pettinari, C.; Marchetti, F.; Kamu, E.; Nagy, L.; Troyanov, S.; Pellerito, L.; J. Inorg. Biochem. 2003, 97, 370.

36. Crowe, A. J.; Smith, P. J.; J. Organomet. Chem. 1982, 224 , 223.

37. Harrison, P. G.; Molloy, K. C.; J. Organomet. Chem. 1978, 152, 63.

38. Isaacs, N. W.; Kennard, C. H. L.; J. Chem. Soc. 1970, A, 1257. 